\title{
Pelatihan PTK: Alternatif Solusi Dalam Meningkatkan Kemampuan Guru Menyusun Karya Tulis Ilmiah
}

\author{
Ekawarna, M. Salam \\ FKIP Universitas Jambi, Indonesia \\ Email : eka.wama@unja.ac.id
}

\begin{abstract}
ABSTRAK
Tujuan kegiatan ini adalah meningkatnya kemampuan guru dalam menyusun proposal, pelaksanaan penelitian dan penyusunan laporan hasil PTK untuk dijadikan sebagai karya publikasi ilmiah untuk memperoleh angka kredit maksimal. Metode yang digunakan adalah pembelajaran orang dewasa (andragogi), dengan rasio 30\% teori (36 Jam Pertemuan/JP) dan 70\% praktek (84 Jam Pertemuan/JP). Peserta berjumlah 24 orang yang berkualifikasi S-1 sebanyak 91,66\%, 8,44\% berkualifikasi D-2. Peserta yang berasal dari SD negeri 79,16\%, 21,84\% berasal dari SD swasta. Hasil yang dicapai: (a) 95\% Guru memiliki kompetensi dalam menilai kegiatan pengembangan profesi guru yang sesuai dengan pedoman agar tujuan kegiatan pengembangan profesi guru dapat dicapai. (b) 100\% Guru mengetahui dan memahami alasan dan saran yang jelas, santun, serta memberikan dampak pembelajaran untuk perbaikan bagi guru itu sendiri. (c) $87 \%$ kemampuan guru meningkat dalam menyusun proposal, pelaksanaan penelitian dan penyusunan laporan hasil PTK untuk dijadikan sebagai karya publikasi ilmiah untuk memperoleh angka kredit maksimal. Implikasi kegiatan adalah; (1) Kegiatan Pelatihan Peningkatan Kompetensi Guru Dalam Menyusun KTI Hasil PTK perlu terus diupayakan, karena hampir semua guru membutuhkan kemampuan tersebut terutama untuk menunjang karier dan peningkatan kesejahteraan yaitu kenaikan pangkat. (2) Pemerintah daerah perlu menganggarkan dana untuk pelaksanaan kegiatan Penelitian Tindakan Kelas (PTK) bagi guru yang berasal dari APBD Provinsi atau Kabupaten/Kota. (3) Dosen di LPTK Unniversitas Jambi perlu terus mengupayakan kegiatan pembimbingan PTK baik melalui program penelitian kolaboratif Dosen-Guru.
\end{abstract}

Kata Kunci : PTK, Karya Tulis Ilmiah, Dosen, Guru

\section{PENDAHULUAN}

Hingga saat ini pemerintah terus melakukan upaya untuk mewujudkan guru profesional. Upaya meningkatkan kualifikasi, kompetensi dan kompensasi guru secara sistemik dan berkesinambungan terus dilakukan dan diperbaiki. Upaya tersebut adalah penting dan strategis, karena Guru adalah ujung tombak pembangunan pendidikan, yang sangat menentukan kualitas hasil dan proses pendidikan. Upaya untuk mewujudkan guru profesional yang bermartabat dan beradab, masih memerlukan bekal kepribadian yang berawal dari motivasi menjadi guru sebagai panggilan hidupnya, mengingat guru bukanlah jenis "manusia super", melainkan manusia biasa, sama dengan manusia biasa lainnya. Yang membedakannya dari manusia yang bukan guru adalah niat atau motivasinya, dedikasinya, idealismenya, kompetensinya dan profesionalismenya" (Surakhmad, 2006). PP No.19/2005 pasal 28 dan Draf PP Guru menyatakan; "kompetensi kepribadian guru adalah kemampuan kepribadian yang mantap, stabil, dewasa, arif, berwibawa, menjadi teladan bagi peserta didik dan masyarakat, mampu mengevaluasi kinerjanya sendiri, dan mengembangkan diri secara berkelanjutan". Gage (1978) mempertegas bahwa "the scientific basic of the art of teaching" 
adalah kemampuan serta kebiasaan guru mengembangkan profesionalitas dirinya secara berkelanjutan.

Pendidik adalah agen pembelajaran yang harus memiliki empat jenis kompetensi, yakni, kompetensi pedagogik, kepribadian, profesional dan sosial. (Pasal 28 PP No. 19 Tahun 2005, tentang Standar Nasional Pendidikan). Penguasaan empat kompetensi tersebut mutlak harus dimiliki setiap guru untuk menjadi tenaga pendidik yang profesional seperti yang disyaratkan Undang-Undang Guru dan Dosen. Kompetensi guru dapat diartikan sebagai kebulatan pengetahuan, keterampilan dan sikap yang ditampilkan dalam bentuk perilaku cerdas dan penuh tanggung jawab yang dimiliki seorang guru dalam menjalankan profesinya. Tanpa bermaksud mengabaikan salah satu kompetensi yang harus dimiliki seorang guru, kompetensi kepribadian kiranya harus mendapatkan perhatian yang lebih. Sebab, kompetensi ini akan berkaitan dengan idealisme dan kemampuan untuk dapat memahami dirinya sendiri dalam kapasitas sebagai pendidik. Pada Pedoman Sertifikasi Kompetensi Pendidik (2004) memuat standar kompetensi kepribadian guru terkait dengan profesionalismenya, yakni kemampuan; (1) menyesuaikan diri dengan lingkungan kerjanya; (2) menilai kinerjanya sendiri; (3) bekerja mandiri dan bekerjasama dengan orang lain; (4) mencari sumber-sumber baru dalam bidang studinya; (5) komitmen terhadap profesi dan tugas profesional; (6) berkomunikasi dengan teman sejawat dan peserta didik; dan (7) meningkatkan diri dalam kinerja profesinya.

Secara lebih specifik kompetensi kepribadian guru tersebut dijabarkan sebagai berikut; (1) selalu menampilkan diri sebagai pribadi mantap, stabil, dewasa, arif, dan berwibawa yang ditandai, antara lain melalui pembiasaan diri dalam; menerima dan memberi kritik dan saran, mentaati peraturan, konsisten dalam bersikap dan bertindak, meletakkan persoalan sesuai pada tempatnya; dan melaksanakan tugas secara mandiri, tuntas, dan bertanggung jawab; (2) selalu menampilkan diri sebagai pribadi yang berakhlak mulia dan sebagai teladan bagi murid dan masyarakat yang tercermin melalui pembiasaan diri dalam; berprilaku santun, berprilaku mencerminkan ketaqwaan, dan berprilaku yang dapat diteladani oleh murid dan masyarakat; (3) berprilaku sebagai pendidik profesional yang dicirikan, antara lain; membiasakan diri menerapkan kode etik profesi guru dalam kehidupan sehari-hari, menunjukkan komitmen sebagai pendidik, dan mengembangkan etos kerja secara bertanggung jawab; (4) mampu mengembangkan diri secara terus menerus sebagai pendidik yang dicirikan keinginan melatih diri dalam memanfaatkan berbagai sumber untuk meningkatkan pengetahuan/ketrampilan/dan kepribadian, mengikuti berbagai kegiatan yang menunjang pengembangan profesi keguruan, melakukan berbagai kegiatan yang memupuk kebiasaan membaca dan menulis, mengembangkan dan menyelenggarakan kegiatan yang menunjang profesi guru; (5) mampu menilai kinerjanya sendiri yang dikaitkan dalam pencapaian utuh pendidikan yang dicirikan antara lain; mengkaji strategi berfikir reflektif untuk melakukan penilaian kinerja sendiri, memecahkan masalah dan meningkatkan kinerjanya untuk kepentingan pendidikan, membiasakan diri menilai kinerjanya sendiri dan melakukan refleksi untuk perbaikan di masa depan, dan menindaklanjuti hasil penilaian kinerjanya untuk kepentingan peserta didik; (6) mampu meningkatkan kualitas pembelajaran melalui penelitian tindakan kelas (PTK), dan riset lainnya (7) mampu berkomunikasi secara efektif dengan orang tua peserta didik, sesama pendidik, dan masyarakat dalam program pembelajaran khususnya dan peningkatan kulitas pendidikan umumnya, bersikap inovatif, adaptif dan kritis terhadap lingkungannya.

Sejatinya guru saat ini sudah memiliki kemampuan untuk menulis karya ilmiah hasil PTK, sebab bahan kajian PTK atau pengalaman belajar PTK sudah diperoleh semasa masih kuliah di S-1 atau melalui pelatihan-pelatihan yang diselenggarakan pemerintah melalui 
pelatihan on-job training. Namun kenyataannya tidak demikian, berdasarkan hasil observasi sementara, $80 \%$ guru mengalami kesulitan dalam membuat karya tulis ilmiah hasil PTK yang dibutuhkan atau merupakan syarat utama dalam mememenuhi kredit point untuk kenaikan pangkat. Oleh karena itu, pelatihan menulis karya tulis ilmiah hasil PTK sangat dibutuhkan pendidik untuk meningkatkan kompetensi personal dan profesional mereka.

\section{TINJAUAN LITERATUR}

Manajemen sumber daya manusia adalah suatu proses mendayagunakan manusia sebagai tenaga kerja secara manusiawi, agar potensi fisik dan psikis yang dimilikinya berfungsi maksimal bagi pencapaian tujuan organisasi. Sumber daya manusia merupakan aset paling berharga dan memiliki peranan yang sangat strategis dalam keberadaan serta keberlangsungan hidup suatu organisasi. Sumber daya manusia sangat dibutuhkan di setiap bidang pekerjaan guna menghasilkan produktivitas kerja sehingga roda organisasi dapat berjalan secara berkualitas dan berkesinambungan. Sehingga peningkatan kualitas sumber daya manusia adalah upaya yang memiliki urgensi tinggi dalam meningkatkan kualitas proses dan hasil organisasi. Kualitas sumber daya manusia dapat dibentuk dengan usaha langsung dan tidak langsung melalui pengembangan kemampuan pengetahuan, sikap dan keterampilan. Pendidikan dan pelatihan merupakan alternative solusi dalam pengembangan kualitas sumber daya manusia. Merujuk Undang Undang Nomor 20 Tahun 2003 tentang Sistem Pendidikan Nasional mendefinisikan pendidikan sebagai usaha sadar dan terencana untuk mewujudkan suasana belajar dan proses pembelajaran agar peserta didik secara aktif mengembangkan potensi dirinya untuk memiliki kekuatan spiritual keagamaan, pengendalian diri, kepribadian, kecerdasan, akhlak mulia, serta keterampilan yang diperlukan dirinya dan masyarakat. Jika ditinjau dari tujuannya, menurut Manpower Services Commissions dalam Suparman (2010), pendidikan adalah kegiatan yang bertujuan untuk mengembangkan pengetahuan, sikap dan keterampilan, pemahaman dan penyerapan, nilai-nilai yang diperlukan dalam semua aspek kehidupan, bukan hanya pengetahuan dan keterampilan yang berhubungan dengan kegiatan atau pekerjaan tertentu. Dari dua konsep tersebut masing-masing menekankan kepada perubahan individu yang terkait dengan nilai-nilai, kemampuan kognitif dan psikomotor melalui pengembangan potensi diri secara terencana. Lebih lanjut dapat dijelaskan bahwa pendidikan dilakukan untuk menyiapkan individu mengarungi kehidupan, yang tidak dibatasi oleh pekerjaan saat ini atau masa yang akan datang.

Sedangkan pelatihan adalah pengalaman pembelajaran yang disiapkan oleh organisasi untuk meningkatkan kinerja pegawai (Nadler dalam Suparman, 2010). Secara operasional, pelatihan merupakan kegiatan yang didesain untuk membantu pegawai memperoleh pengetahuan keterampilan dan perilaku untuk melaksanakan tugas-tugasnya, sehingga tujuan organisasi dapat tercapai. Pelatihan berorientasi pada pekerjaan saat ini atau masa datang. Pelatihan menurut Nitisemito (1996:35), mendefinisikan pelatihan atau training sebagai suatu kegiatan yang bermaksud untuk memperbaiki dan mengembangkan sikap, tingkah laku ketrampilan, dan pengetahuan dari karyawannya sesuai dengan keinginan perusahaan. Menurut Carrell dan Kuzmits (1982:282) mendefinisikan pelatihan sebagai proses sistematis dimana karyawan mempelajari pengetahuan (knowledge), ketrampilan (skill), kemampuan (ability) atau perilaku terhadap tujuan pribadi dan organisasi. Menurut Drummond (1990:63), "pelatihan berarti menuntun dan mengarahkan perkembangan dari peserta pelatihan melalui pengetahuan, keahlian dan sikap yang diperoleh untuk memenuhi standar tertentu. Menurut 
Simamora (1999:345), pelatihan adalah serangkaian aktifitas yang dirancang untuk meningkatkan keahlian-keahlian, pengetahuan pengalaman atau perubahan sikap seseorang. Mangkuprawira (2003:135) berpendapat bahwa pelatihan bagi karyawan adalah sebuah proses mengajarkan pengetahuan dan keahlian tertentu serta sikap agar karyawan semakin trampil dan mampu dalam melaksanakan tanggung jawabnya dengan semakin baik sesuai dengan standar. Definisi lebih lanjut dikemukakan Mangkuprawira yang memberikan perbedaan pada pengertian pelatihan dan pendidikan. Pelatihan lebih merujuk pada pengembangan keterampilan dalam bekerja (vocational) yang dapat digunakan dengan segera, sedangkan pendidikan memberikan pengetahuan tentang subyek tertentu, tetapi sifatnya lebih umum, terstruktur untuk jangka waktu yang jauh lebih panjang. Moekijat (1991:2) mendefinisikan pelatihan merupakan usaha yang bertujuan untuk menyesuaikan seseorang dengan lingkungannya, baik itu lingkungan di luar pekerjaan, maupun lingkungan di dalamnya.

Penelitian Tindakan Kelas (PTK) adalah penelitian tindakan (action research) yang dilaksanakan oleh guru di dalam kelas. Penelitian tindakan pada hakikatnya merupakan rangkaian "riset-tindakan-riset-tindakan- ..." yang dilakukan secara siklik dalam rangka memecahkan masalah, sampai masalah itu terpecahkan. Berikut dikemukakan beberapa definisi tentang PTK antara lain; Hopkins (1993), PTK adalah penelitian yang mengkombinasikan prosedur penelitian dengan tindakan substantif, suatu tindakan yang dilakukan dalam disiplin inquiri, atau suatu usaha seseorang untuk memahami apa yang sedang terjadi, sambil terlibat dalam sebuah proses perbaikan dan perubahan. Rapoport (1970), PTK adalah penelitian untuk membantu seseorang dalam mengatasi secara praktis persoalan yang dihadapi dalam situasi darurat dan membantu pencapaian tujuan ilmu sosial dengan kerjasama dalam kerangka etika yang disepakati bersama. Kemmis (1983). PTK adalah sebuah bentuk inquiri reflektif yang dilakukan secara kemitraan mengenai situasi sosial tertentu (termasuk pendidikan). Ebbutt (1985), PTK adalah kajian sistematik dari upaya perbaikan pelaksanaan praktek pendidikan oleh sekelompok guru dengan melakukan tindakan-tindakan dalam pembelajaran, berdasarkan refleksi mereka mengenai hasil dari tindakan-tindakan tersebut. Elliott (1991), PTK adalah kajian dari sebuah situasi sosial dengan kemungkinan tindakan untuk memperbaiki kualitas situasi sosial tersebut. Arikunto (2006), PTK merupakan suatu pencermatan terhadap kegiatan pembelajaran berupa sebuah tindakan, yang sengaja dimunculkan dan terjadi dalam sebuah kelas secara bersamaan. Kunandar (2008), PTK merupakan suatu kegiatan yang dilakukan oleh Guru atau bersama-sama dengan orang lain (kolaborasi) yang bertujuan untuk memperbaiki atau meningkatkan mutu proses pembelajaran di kelasnya.

PTK termasuk penelitian kualitatif walaupun data yang dikumpulkan bisa saja bersifat kuantitatif. PTK berbeda dengan penelitian formal, yang bertujuan untuk menguji hipotesis dan membangun teori yang bersifat umum (general). PTK lebih bertujuan untuk memperbaiki kinerja, sifatnya kontekstual dan hasilnya tidak untuk digeneralisasi. Namun demikian hasil PTK dapat saja diterapkan oleh orang lain yang mempunyai latar yang mirip dengan yang dimiliki peneliti. Berdasarkan karakteristik PTK, maka tujuan guru melaksanakan PTK adalah dalam rangka memperbaiki cara-cara mengajar melalui penerapan metode baru atau tindakan baru yang dia temukan dan diyakini karena metode baru itu telah teruji ternyata efektif meningkatkan hasil pembelajaran seperti yang diharapkan. Tujuan akhirnya melalui PTK akan menghasilkan peningkatan baik kualitas proses maupun kualitas hasil belajar siswa. Dengan senantiasa memperbaiki cara-cara mengajarnya itu, guru diharapkan dapat memecahkan permasalahan nyata yang terjadi di dalam kelas. Disamping hal di atas, melalui PTK guru 
tidak sekadar bertujuan untuk memecahkan masalah, melainkan juga mencari jawaban ilmiah terhadap masalah yang dihadapinya. Secara lengkap tujuan PTK adalah sebagai berikut; (a) Memperbaiki dan meningkatkan mutu praktik pembelajaran yang dilaksanakan guru demi tercapainya tujuan pembelajaran yang bermutu. (b) Memperbaiki dan meningkatkan kinerjakinerja pembelajaran yang dilaksanakan oleh guru. (c) Mengidentifikasi, menemukan solusi, dan mengatasi masalah pembelajaran di kelas agar pembelajaran bermutu. (d) Meningkatkan dan memperkuat kemampuan guru dalam memecahkan masalah-masalah pembelajaran dan membuat keputusan yang tepat bagi siswa dan kelas yang diajarnya. (e) Mengeksplorasi dan membuahkan kreasi-kreasi dan inovasi-inovasi pembelajaran (misalnya, pendekatan, metode, strategi, dan media) yang dapat dilakukan oleh guru demi peningkatan mutu proses dan hasil pembelajaran. (f) Mencobakan gagasan, pikiran, kiat, cara, dan strategi baru dalam pembelajaran untuk meningkatkan mutu pembelajaran selain kemampuan inovatif guru. (g) Mengeksplorasi pembelajaran yang selalu berwawasan atau berbasis penelitian agar pembelajaran dapat bertumpu pada realitas empiris kelas, bukan semata-mata bertumpu pada kesan umum atau asumsi. Tujuan-tujuan di atas pada prinsipnya mengarah pada adanya upaya-upaya tindakan yang dilakukan oleh guru untuk meningkatkan mutu isi, mutu masukan, mutu proses, dan mutu hasil pendidikan dan pembelajaran di dalam kelas. Peningkatan pada aspek-aspek ini pada akhirnya dapat digunakan untuk meningkatkan sikap profesional guru dan menumbuhkan budaya akademik di lingkungan sekolah sehingga tercipta sikap proaktif di dalam melakukan perbaikan mutu pendidikan dan pembelajaran secara berkelanjutan.

\section{METODE PELAKSANAAN}

\section{Sasaran Latih}

Sasaran latih dari program pelatihan PTK sebagai upaya peningkatan kualitas hasil belajar siswaini adalah 24 guru SD di Kecamatan Tebing Tinggi, Kabupaten Tanjung Jabung Barat, Provinsi Jambi. Peserta berkualifikasi S-1 sebanyak 91,66\%, 8,44\% berkualifikasi D-2. Peserta yang berasal dari SD negeri sebanyak 79,16\%, 21,84\% berasal dari SD swasta.

\section{Materi Pelatihan}

Adapun rincian materi kegiatan dan alokasi waktu yang disediakan dirinci sebagaimana yang disajikan pada TABEL 1 berikut:

Tabel 1. Materi pelatihan peningkatan Kompetensi guru dalam menyusun karya tulis ilmiah hasil PTK

\begin{tabular}{|c|c|c|c|c|c|}
\hline \multirow[t]{2}{*}{ No } & \multirow{2}{*}{ MATERI PELATIHAN } & \multicolumn{2}{|c|}{$\begin{array}{l}\text { ALOKASI } \\
\text { WAKTU }\end{array}$} & \multirow[t]{2}{*}{ INSTRUKTUR } & \multirow[t]{2}{*}{ TEMPAT } \\
\hline & & $\begin{array}{l}\text { Teori } \\
\mathbf{3 0 \%}\end{array}$ & $\begin{array}{c}\text { Praktek } \\
\mathbf{7 0 \%}\end{array}$ & & \\
\hline 1. & $\begin{array}{l}\text { Konsep Dasar dan } \\
\text { Penyusunan Proposal } \\
\text { Penelitian Tindakan Kelas }\end{array}$ & $8 \mathrm{JP}$ & - & $\begin{array}{l}\text { Drs. M. Salam, } \\
\text { M.Si }\end{array}$ & $\begin{array}{l}\text { SD inti Kec. } \\
\text { Tebing Tingg } \\
\text { Tanjabar }\end{array}$ \\
\hline 2. & $\begin{array}{l}\text { Penyusunan laporan hasil } \\
\text { PTK }\end{array}$ & $8 \mathrm{JP}$ & - & $\begin{array}{l}\text { Prof. Dr. Ekawarna, } \\
\text { M.Psi }\end{array}$ & $\begin{array}{l}\text { SD inti Kec. } \\
\text { Tebing Tingg } \\
\text { Tanjabar }\end{array}$ \\
\hline 3. & Pembimbingan penyusunan & $20 \mathrm{JP}$ & $84 \mathrm{JP}$ & Prof. Dr. Ekawarna, & Kampus \\
\hline
\end{tabular}




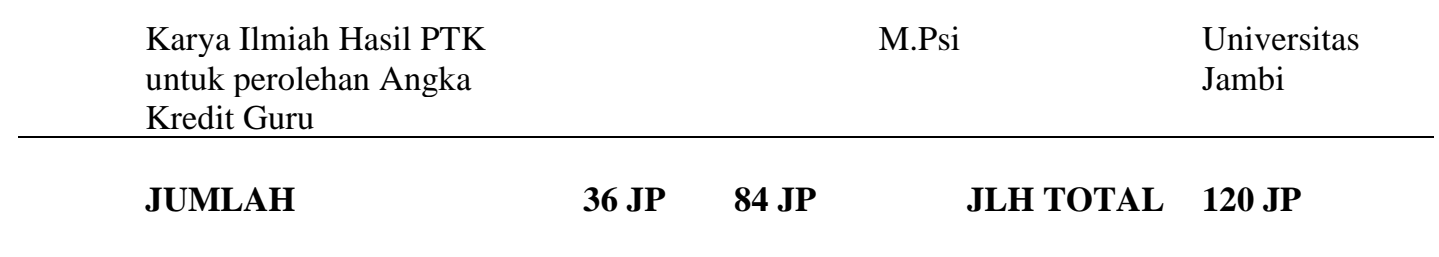

Catatan : JP = Jam Pertemuan, satu jam pertemuan eqivalen dengan 45 menit.

\section{Strategi Pembelajaran}

Materi yang diberikan melalui metode pembelajaran orang dewasa (andragogi), dengan rasio 30\% teori (36 Jam Pertemuan/JP) dan 70\% praktek (84 Jam Pertemuan/JP). Pada pembelajaran orang dewasa, lebih menitikberatkan pada peningkatan kualitas kehidupan mereka, memberikan ketrampilan dan kemampuan untuk memecahkan permasalahan yang mereka alami dalam hidup dan tugas pengabdiannya. Dengan demikian diharapkan pada akhir pembelajaran peserta latih akan dapat mengarahkan diri sendiri dan menjadi guru untuk dirinya sendiri. Pada tahap pembelajaran materi teori, peserta dikumpulkan bersama kemudian tenaga pelatih menyampaikan materi yang telah dipersiapkan.

\section{Lokasi Penyelenggaraan}

Lokasi penyelenggaraan pelatihan peningkatan kompetensi guru dalam menyusun karya tulis ilmiah hasil PTK bertempat di KKG Kecamatan Tebing Tinggi Kabupaten Tanjung Jabung Barat (120 KM dari Universitas Jambi).

\section{HASIL DAN PEMBAHASAN}

Berdasarkan hasil evaluasi yang dilakukan setelah pelatihan selesai, hasil yang dicapai dari Kegiatan Pelatihan Peningkatan Kompetensi Guru Dalam Menyusun KTI Hasil PTK Pada Guru SD Di Kecamatan Tebing Tinggi Kabupaten Tanjung Jabung Barat Provinsi Jambi Tahun 2019, adalah berupa tercapainya Output yaitu sebagai berikut: (a) 95\% Guru memiliki kompetensi dalam menilai kegiatan pengembangan profesi guru yang sesuai dengan pedoman agar tujuan kegiatan pengembangan profesi guru dapat dicapai. (b) 100\% Guru mengetahui dan memahami alasan dan saran yang jelas, santun, serta memberikan dampak pembelajaran untuk perbaikan bagi guru itu sendiri. (c) $87 \%$ kemampuan guru meningkat dalam menyusun proposal, pelaksanaan penelitian dan penyusunan laporan hasil PTK untuk dijadikan sebagai karya publikasi ilmiah untuk memperoleh angka kredit maksimal. Salah satu bagian dari pendidik yang banyak memberikan bekal bagi terbentuknya kualitas sumber daya manusia yaitu pelatihan. Pelatihan secara umum merupakan keseluruhan aktivitas yang dirancang untuk meningkatkan potensi atau kinerja peserta dalam melaksanakan pekerjaan mereka, dan pelatihan menjadi bagian dari pengembangan sumber daya manusia. Peraturan Pemerintah RI no.19 tahun 2005 tentang Standar Nasional Pendidikan Pasal 6 Ayat 3 menyatakan bahwa: Satuan pendidikan nonformal dalam bentuk kursus dan pelatihan menggunakan kurikulum berbasis kompetensi yang memuat pendidikan kecakapan hidup dan keterampilan. Peran pelatihan sangat diperlukan dalam menunjang kegiatan pendidikan untuk menciptakan sumber daya manusia yang berkualitas dan profesional. Oemar Hamalik (2007: 10) menyampaikan bahwa "Pelatihan merupakan suatu fungsi manajemen yang perlu dilaksanakan terus-menerus dalam rangka pembinaan ketenagaan dalam suatu organisasi". Oleh karena itu, pelatihan memiliki peran penting sebagai tindakan (upaya) dan proses dalam meningkatkan keterampilan yang dilaksanakan secara berkesinambungan, bertahap, terkelola, 
serta terarah untuk mencapai tujuan tertentu terkait dengan pencapaian tujuan organisasi. Pelatihan diselenggarakan karena mempunyai tujuan dan manfaat. Agar tujuan dan manfaat tersebut dapat tercapai dengan baik sesuai dengan sasaran yang telah ditentukan maka pelatihan harus dikelola dengan baik. Manajemen pelatihan yang optimal akan menghasilkan efektivitas pencapaian sasaran pelatihan. Pelaksanaan pelatihan seyogyanya dapat dikelola secara maksimal karena berpengaruh pada kualitas output pelatihan sesuai dengan peraturanperaturan yang telah dibuat sebagai pedoman manajemen pelatihan. Pernyataan tersebut sejalan dengan UU no 20 tahun 2003 tentang Sistem Pendidikan Nasional pasal 26 ayat 7 bahwa: Ketentuan mengenai penyelenggaraan pendidikan nonformal sebagaimana dimaksud dalam ayat (1), ayat (2), ayat (3), ayat (4), ayat (5), dan ayat (6) diatur lebih lanjut dengan Peraturan Pemerintah. Pernyataan tersebut mengandung arti bahwa manajemen pelatihan perlu dikelola dengan baik karena menjadi salah satu faktor penentu keberhasilan dan tercapainya tujuan pelatihan. Anwar Prabu Mangkunegara (2005: 49) mengemukakan tujuan utama pelatihan secara luas yang dikelompokkan menjadi sembilan bidang yaitu: 1) Meningkatkan penghayatan jiwa dan ideologi 2) Meningkatkan produktivitas kerja; 3) Meningkatkan kualitas kerja; 4) Meningkatkan ketetapan perencanaan sumber daya manusia; 5) Meningkatkan sikap moral dan semangat kerja; 6) Meningkatkan rangsangan agar pegawai mampu berprestasi secara maksimal; 7) Meningkatkan kesehatan dan keselamatan kerja; 8) Meningkatkan keusangan (obsolescence); 9) Meningkatkan perkembangan skill pegawai.

Dengan demikian, pengelolaan pelatihan diperlukan dalam menciptakan pelatihan yang tersistem dan terkelola dengan baik sehingga tujuan dapat tercapai. Manajemen berasal dari kata to manage yang artinya mengatur. Pengaturan dilakukan melalui proses dan diatur berdasarkan urutan dari fungsi-fungsi manajemen. Irawan (1997: 5) mendefinisikan bahwa "Pengelolaan sama dengan manajemen yaitu penggerakkan, pengorganisasian dan pengarahan usaha manusia untuk memanfaatkan secara efektif material dan fasilitas untuk mencapai suatu tujuan". Oleh karena itu, istilah manajemen dalam penelitian ini dapat disebut juga dengan pengelolaan melalui proses fungsi-fungsi manajemen. Manajemen pelatihan merupakan rangkaian proses pelatihan yang dikelola melalui berbagai prosedur atau kegiatan diantaranya perencanaan pelatihan, pelaksanaan pelatihan, dan evaluasi pelatihan dengan pemanfaatan sumber daya manusia, informasi, sistem dan sumber dana dengan tetap memperhatikan fungsi manajemen, peran dan keahlian untuk menghasilkan pelatihan sesuai dengan tujuan dan bermanfaat bagi peserta. Haris Mudjiman (2006: 57) menyampaikan ada 5 (lima) unsur pokok dalam manajemen pelatihan, kelima unsur tersebut adalah "analisis kebutuhan pelatihan, perencanaan pelatihan, penyusunan bahan pelatihan, pelaksanaan pelatihan, dan penilaian pelatihan". Oleh karena itu, manajemen pelatihan atau pengelolaan pelatihan adalah sama sehingga pada penelitian ini akan memakai istilah manajemen pelatihan. Manajemen pelatihan meliputi perencanaan pelatihan, pelaksanaan pelatihan, dan evaluasi pelatihan.

Perencanaan dilakukan di awal untuk memiliki dan menetapkan tujuan. Perencanaan pelatihan dilakukan saat pelatihan telah disepakati akan diselenggarakan. Tujuan pelatihan yang telah ditetapkan selanjutnya pengelola pelatihan dapat menentukan kebutuhan pelatihan, strategi, metode, sistem, kurikulum, materi, dan desain untuk mencapai tujuan tersebut. Sutarno NS (2004: 109) menyatakan bahwa:

Perencanaan diartikan sebagai perhitungan dan penentuan tentang apa yang akan dijalankan dalam rangka mencapai tujuan tertentu, dimana menyangkut tempat, oleh siapa pelaku itu atau pelaksana dan bagimana tata cara mencapai tujuan. Pelatihan akan berjalan secara optimal apabila telah ditetapkan tujuan dan dikelola dengan baik. Tujuan pelatihan 
pada hakikatnya adalah perumusan kemampuan yang diharapkan dari pelatihan yaitu adanya perubahan perilaku. Dari penentuan tujuan dan sasaran pelatihan akan dapat diketahui kemampuan-kemampuan apa yang harus diberikan dalam pelatihan. Maka selanjutnya dapat diidentifikasi desain dari pelatihan. Haris Mudjiman (2006: 64) menyampaikan 9 (sembilan) poin kegiatan perencanaan pelatihan meliputi: 1) Menetapkan pengelola dan staf pembantu program pelatihan; 2) Menetapkan tujuan pelatihan; 3) Menetapkan bahan ajar pelatihan; 4) Menetapkan metode-metode yang akan digunakan; 5) Menetapkan alat bantu pelatihan; 6) Menetapkan cara evaluasi pelatihan; 7) Menetapkan tempat dan waktu pelatihan; 8) Menetapkan instruktur pelatihan; 9) Menyusun rencana kegiatan dan jadwal pelatihan, dan menghitung anggaran yang dibutuhkan. Dengan demikian, perencanaan dilakukan pada awal sebelum pelatihan terselenggara merupakan langkah awal dalam manajemen pelatihan dengan menetukan pengelola pelatihan. Pelaksanaan pelatihan dengan susunan pengelola yang berhasil akan membuat terselenggaranya pelatiahan dapat mencapai tujuannya.

Unsur yang kedua dalam manajemen pelatihan adalah pelaksanaan pelatihan. Setelah merencanakan kebutuhan pelatihan, maka tahap selanjutnya mengaplikasikan perencanaan pelatihan yang telah ditentukan sebelumnya. Implementasi perencanaan pelatihan dapat dilihat dari tugas dan wewenang pengelola telah sesuai, tujuan pelatihan dapat tercapai, waktu, jadwal alokasi penyelenggaraan, tempat, media, dan metode yang digunakan. Haris Mudjiman (2006: 66) menyatakan bahwa dalam pelaksanaan pelatihan harus memperhatikan langkah-langkah yang meliputi "tahap perkenalan, acara review pengalaman, dan dirangsang untuk memanfaatkan pengalaman”. Dengan kata lain, Haris Mudjiman menyampaikan bahwa dalam pelaksanaan pelatihan perlu adanya tahapan-tahapan proses penyampaian kepada peserta agar partisipan memahami tujuan dan manfaat yang akan diperoleh.

Tahapan dari manajemen pelatihan yang terakhir adalah evaluasi. Kekurangan atau kegagalan sering terjadi dalam pelaksanaan program pelatihan, sehingga terjadi kesalahankesalahan yang tidak diinginkan dalam usaha pencapaian tujuan. Penilaian memiliki peran penting dalam memperoleh hasil akhir suatu proses kegiatan, salah satunya dalam proses pelatihan. Kegiatan penilaian memerlukan media dalam menghimpun informasi-informasi yang menjadi dasar dilakukannya penilaian. Jackie dkk (2005: 82) mengatakan bahwa: Efektivitas bentuk evaluasi akan terganggu jika format terlalu panjang dan kompleks. Anda bisa merancang bentuk evaluasi sesuai dengan karakter dan skala usaha anda. Hasil evaluasi dapat berupa skala derajad pencapaian. Misalnya: Tidak memuaskan (TM), Di bawah ratarata (DR), Rata-rata (R), Memuaskan (M), Luar Biasa (LB). Pernyataan Jackie dkk mengandung arti bahwa alat evaluasi seyogyanya menggunakan indikator yang sederhana tetapi dapat mencangkup penilaian keseluruhan. Sedangkan dalam hasil evaluasi dapat menggambarkan kesimpulan kegiatan yang telah dinilai. Evaluasi pelatihan dilakukan secara sistematis kepada peserta pelatihan. Kegiatan ini dilakukan karena program pelatihan perlu memperhatikan evaluasi (feed back) dari peserta yang mengikuti program pelatihan. Veithzal Rivai \& Ella Jauvani (2009: 233) menyampaikan ada 4 (empat) kriteria efektif untuk mengevaluasi kegiatan pelatihan dengan berfokus pada hasil akhir, antara lain: 1) Reaksi dari para peserta pelatihan terhadap proses dan isi kegiatan pelatihan; 2) Pengetahuan atau proses belajar yang diperoleh melalui pengalaman pelatihan; 3) Perubahan perilaku yang disebabkan karena kegiatan pelatihan; dan 4) Hasil atau perbaikan yang dapat diukur baik secara individu maupun organisasi, seperti makin rendahnya turnover (berhenti kerja), makin sedikit kecelakaan, makin kecilnya ketidakhadiran, makin menurunnya kesalahan kerja, makin efisiennya penggunaan waktu dan biaya, seta makin produktifnya karyawan, dan lain-lain. 
Penyelenggaraan program pelatihan dapat dikatakan berhasil apabila dalam diri peserta pelatihan terjadi suatu proses transformasi. Transformasi tersebut dapat dinyatakan langsung dari peningkatan kemampuan dalam melaksanakan tugas dan perubahan perilaku yang tercermin pada sikap, disiplin, dan etos kerja. Esensi kompetensi kepribadian guru semuanya bermuara ke dalam intern pribadi guru.

Kompetensi pedagogik, profesional dan sosial yang dimiliki seorang guru dalam melaksanakan pembelajaran, pada akhirnya akan lebih banyak ditentukan oleh kompetensi kepribadian yang dimilikinya. Tampilan kepribadian guru akan lebih banyak memengaruhi minat dan antusiasme anak dalam mengikuti kegiatan pembelajaran. Pribadi guru yang santun, respek terhadap siswa, jujur, ikhlas dan dapat diteladani, mempunyai pengaruh yang signifikan terhadap keberhasilan dalam pembelajaran apa pun jenis mata pelajarannya. Oleh karena itu, dalam beberapa kasus tidak jarang seorang guru yang mempunyai kemampuan mumpuni secara pedagogis dan profesional dalam mata pelajaran yang diajarkannya, tetapi implementasinya dalam pembelajaran kurang optimal. Hal ini boleh jadi disebabkan tidak terbangunnya jembatan hati antara pribadi guru yang bersangkutan sebagai pendidik dan siswanya, baik di kelas maupun di luar kelas. Upaya pemerintah meningkatkan kemampuan pedagogis dan professional guru banyak dilakukan, baik melalui pelatihan, workshop, maupun pemberdayaan musyawarah guru mata pelajaran (MGMP). Akan tetapi, hal tersebut kurang menyentuh peningkatan kompetensi kepribadian guru. Kegiatan pengabdian kepada masyarakat yang dikemas dalam pelatihan PTK telah membuktikan bahwa kegiatan pelatihan telah mampu meningkatkan kompetensi pribadi sekaligus kompetensi pedagogis dan kompetensi profesional tenaga pendidik.

Kita patut bertanya mengapa pendidikan kita banyak menghasilkan anak didik yang cerdas, pintar dan terampil, tapi belum banyak menghasilkan anak didik yang memiliki kepribadian yang sesuai dengan yang diharapkan. Sehingga, bangsa kita mengalami krisis multidimensional yang berkepanjangan yang tiada ujungnya. Jangan-jangan ini semua buah kita sebagai pendidik yang belum menampilkan kepribadian yang patut diteladani oleh anak didik kita.

\section{KESIMPULAN DAN SARAN}

Dari uraian di atas, maka dapat disimpulkan sebagai berikut. (a) Kegiatan pelatihan telah mencapai target capaian yaitu hasil belajar guru peserta pelatihan yaitu meningkatnya kemampuan guru dalam menyusun proposal, pelaksanaan penelitian dan penyusunan laporan hasil PTK. (b) Guru memperoleh pengalaman belajar baru berupa karya tulis ilmiah hasil PTK untuk dijadikan sebagai karya publikasi ilmiah untuk memperoleh angka kredit maksimal. (c) Karena terkendala jarak tempat pelatihan instruktur tidak berkesempatan untuk memonitor kegiatan praktek pelaksanaan PTK peserta di sekolahnya masing-massing. Walaupun kendala tersebut dapat diatasi dengan menggunakan perangkat Teknologi Informasi dan Komunikasi. Berikut disampaikan saran sebagai berikut. (1) Kegiatan Pelatihan Peningkatan Kompetensi Guru Dalam Menyusun KTI Hasil PTK perlu terus diupayakan, karena hampir semua guru membutuhkan kemampuan tersebut terutama untuk menunjang karier dan peningkatan kesejahteraan yaitu kenaikan pangkat. (2) Pemerintah daerah perlu menganggarkan dana untuk pelaksanaan kegiatan Penelitian Tindakan Kelas (PTK) bagi guru yang berasal dari APBD Provinsi atau Kabupaten/Kota. (3) Dosen di LPTK Unniversitas Jambi perlu terus 
mengupayakan kegiatan pembimbingan PTK baik melalui program kegiatan pengabdian pada masyarakat (PPM), Penugasan Dosen di Sekolah (PDS) atau melalui program penelitian kolaboratif Dosen-Guru.

\section{DAFTAR PUSTAKA}

Anwar Prabu Mangkunegara. (2005). Sumber Daya Manusia Perusahaan. Bandung: Remaja Rosdakarya.

Arikunto, Suharsimi, 2006. Penelitian Tindakan Kelas. Jakarta: Bumi Aksara.

Chourmain, Imam, 2008. Acuan Normatif Penelitian Untuk penulisan Skripsi, Tesis \& Disertasi. Jakarta: Al Haramain Publishing House.

Departemen Pendidikan Nasional, 1999, Penelitian Tindakan kelas (Classroom Action Research). Jakarta: Ditjen Dikti Depdikbud, Proyek Pengembangan Guru Sekolah Menengah.

Ekawarna, 2017, Penelitian Tindakan Kelas. Jakarta: Referensi

Elliot, John, 1991, Action Research Education Change. Philadelphia: Open University Press.

Faris Ihsan, Website BKD dan Diklat Provinsi NTB : http:///bkddiklat.ntbprov.go.id (diakses 28 Agustus 2019).

Haris Mudjiman. (2006). Manajemen Pelatihan Berbasis Belajar Mandiri. Yogyakarta: Pustaka Pelajar.

Hopkins, David, 1993. A Teacher's Guide to Classroom Research. Philadelphia: Open University Press.

Irawan. (1997). Manajemen Sumber Daya Manusia. Jakarta: STIA-LAN Press.

Iskandar, 2009, Penelitian Tindakan Kelas. Jakarta: Gaung Persada Press.

Kemmis \& McTaggart, 1994. The Action Research Planner. Dekan University.

Keputusan Kepala LAN RI nomor 193/XIII/10/6/2001 tentang Pedoman Umum Pendidikan dan Pelatihan Jabatan PNS

Oemar Hamalik. (2007). Manajemen Pelatihan Ketenagakerjaan: Pendekatan Terpadu (Cet.4). Jakarta: PT Bumi Aksara.

Peraturan Menteri Pendayagunaan Aparatur Negara Nomor per/14/M.PAN/2009 tentang Jabatan Fungsional dan Angka Kreditnya.

Peraturan Pemerintah nomor 101 tahun 2000 tentang Pendidikan dan Pelatihan Jabatan PNS.

Peraturan Pemerintah RI no.19 tahun 2005 tentang Standar Nasional Pendidikan. Jakarta: Depdikbud

Siregar, Nelson, 1998. Penelitian Kelas : Teori, Metodologi dan Analisis. Bandung: IKIP Bandung Press.

Supardi, 2006. Penelitian Tindakan Kelas (Classroom Action Research) beserta Sistematika Proposal dan Laporannya. Jakarta: Bumi Aksara.

Suparman, R., 2010, Model Program Pengembangan Karir Pegawai Berbasis Diklat Pada PKP2A1 LAN, Jurnal Diklat Aparatur. Volume 6: Nomor 2 : 2010, PKP2A I LAN, Bandung.

Supriadi, Dedi, 1998. Educatiobal Research in Practice. Bandung: Graduate School of Education, IKIP.

Suprijanto, H, 2005, Pendidikan Orang Dewasa, Bumi Aksara, Jakarta

Undang Undang Nomor 20 Tahun 2003 tentang Sistem Pendidikan Nasional. 
UNDP, 1997, Governance for Sustainable Development A Policy Document, UNDP, New York

Veithzal Rivai \& Ella Jauvani. (2009). Manajemen Sumber Daya Manusia untuk Perusahaan: Dari Teori ke Praktik. Jakarta: PT Raja Grafindo Persada.

Wiriaatmadja, R, 2008. Metode Penelitian Tindakan kelas, Untuk meningkatkan kinerja guru dan dosen. Bandung: Remaja Rosda Karya.

Zuber, Skerritt, Ortrun, 1992. Action Research in Higher Education. London: Kogan Page, Ltd. 